\title{
Taking responsibility for reconciliation: a Christian response to the legacy and challenges of the South African Truth and Reconciliation Commission (TRC)
}

\author{
S. Barry
}

School of Ecclesiastical Science

Potchefstroom Campus

North-West University

POTCHEFSTROOM

E-mail: 3rmethodist@telkomsa.net

\begin{abstract}
Taking responsibility for reconciliation: a Christian response to the legacy and challenges of the South African Truth and Reconciliation Commission (TRC)

At the conclusion of the TRC, Desmond Tutu stated that the Commission's task was to promote, not to achieve, reconciliation. Reconciliation, he maintained, is the responsibility of all South Africans, and expressed the hope that the Christian churches would be in the forefront of this healing process.

This article explores how the Christian church can be in the forefront of binding up the wounds, facilitating the healing process, and living as a people and a sign of hope. The answers it seeks to offer fall under three interrelated themes, namely the church's:
\end{abstract}

- spirituality of reconciliation;

- ministry and mission of reconciliation; and

- resources for its ministry and mission of reconciliation.

Cultivating a spirituality of reconciliation would mean making reconciliation a lifestyle, rather than a series of strategies, programmes or initiatives, yet remaining concrete, practical, measurable and accountable.

The church's mission is primarily to proclaim the good news of God's Kingdom that is already here, but not yet fully here and therefore still to come. This proclamation is the message of 
reconciliation between God, others and the self, and anticipates the unity of all creation in Jesus Christ.

The resources given to the church to fulfil this apostolic ministry include prophecy, evangelism, pastoral care and teaching, as well as its liturgical and sacramental life, its ministry of presence, its people and its commitment to social justice.

\section{Opsomming}

\section{Aanvaar verantwoordelikheid vir rekonsiliasie: 'n Christelike benadering tot die uitdagings en gevolge deur die Waarheid- en Versoeningskommissie nagelaat}

Met die afsluiting van die Waarheid-en Versoeningskommissie, het Desmond Tutu 'n stelling gemaak, dat dit die Kommissie se taak was om versoening te bevorder, nie te bereik nie. Hy het dit voorgehou dat rekonsiliasie die verantwoordelikheid van alle Suid-Afrikaners is, en die hoop uitgespreek dat die Christelike kerke op die voorpunt van hierdie genesingsproses sou wees.

Hierdie artikel ondersoek maniere waarop die Christelike kerk op die voorpunt kan wees as dit kom by die verbinding van wonde, die fasilitering van die genesingsproses, en die daarstelling van 'n lewende voorbeeld van eenheid en hoop. Die antwoorde wat voorgestel word, val uiteen in drie verwante temas, naamlik die kerk se:

- gees van versoening;

- bediening en missie van versoening; en

- hulpbronne vir die bediening en missie van versoening.

Om 'n gees van versoening te kweek, beteken om versoening as 'n leefwyse te ontwikkel eerder as 'n reeks strategieë, programme of inisiatiewe - dit moet steeds konkreet, prakties, meetbaar en verantwoordelik bly.

Die kerk se missie is primêr die verkondiging van die goeie nuus, dat God se Koningkryk reeds hier is, maar nog nie in sy volheid nie, en dus nog moet kom. Hierdie verkondiging is die boodskap van versoening tussen God, ander mense, en die self. Dit plaas die eenheid van die ganse skepping deur Christus in afwagting.

Die hulpbronne aan die kerk verleen om hierdie apostoliese bediening te volbring, sluit profesie, evangelisasie, pastorale sorg en skoling in, asook die kerk se liturgiese en sakramentele elemente, sy bediening deur teenwoordig te wees, sy lede en sy toewyding tot sosiale geregtigheid. 


\section{Introduction}

It is important to remind us all that the TRC is expected to promote, not to achieve reconciliation. Reconciliation has to be the responsibility of all South Africans, a national project - and we hope that the churches and other faith communities will be in the forefront of this healing process which is possibly going to go on for decades. (Desmond Tutu, 1998.)

In a previous article in In die Skriflig (Barry, 2006:691-714), I stated that the TRC's contribution was the following:

- It presented itself as a microcosm of the nation, and as such it could be said to hold out a mirror of who we, the rainbow nation are, and the promise of who we can become.

- It exposed a great deal of truth about our past. It exposed much about the nature and extent of gross, human rights violations; "never again will South Africans be able to say "we did not know"" (Villa-Vicencio, 2000:202). It created a space where narratives of suffering could emerge, thus allowing greater understanding between the sections of South African society separated by the racialised boundaries of apartheid. It "made possible a greater 'fusion of horizons' a base line of understanding, and it defined the parameters of discussion of the past ... The range of permissible lies is now much narrower because of the work of the TRC" (Wilson, 2001:225; italisation - SB). It also revealed much about "the causes, motives and perspectives" of persons responsible for perpetrating human rights violations, and "the extent to which many of the nation's worst perpetrators were themselves victims of a political system and cultural milieu that promoted violence" (Villa-Vicencio, 2000:204); as well as "the capacity of apparently decent people to sink to such a level where they can commit the most atrocious evil" (Villa-Vicencio, 2000:203). Further, it confirmed the necessity of political solutions to prevent further atrocities.

- It facilitated catharsis - indeed reconciliation and healing - for some, but not for all. It also, albeit unintentionally, challenged the nation with the fact that more, much more, is needed than the facilitation of crying in public. It confronted the nation with the need for follow-up and for legislation to make adequate mental health services available.

- It participated in the creation of a democratic, human rights culture and a shift from a punitive to a restorative justice ethic in 
South Africa. Restorative justice, by definition, extends beyond any particular initiative or juridical procedure; it involves a set of attitudes to peace, justice and equality; it demands a commitment to the creation of a criminal justice and legal system that is representative, quick and fair, as well as a commitment to economic justice, of which reparation is but a small part.

- It reminded the nation that reconciliation is both a goal and a process, and of the dangers of mistaking one for the other, as well as the inherent dangers of wanting the goal so much as to force the process, and thus of marginalising dissonant voices. To do so is to ensure that things will go horribly wrong for years to come.

The TRC challenged the Christian church to do business with both its theology and its practice of reconciliation. It was Desmond Tutu (1998:6), the chairperson of the Commission, who challenged the Christian community to "be in the forefront of this healing process which is possibly going to go on for decades".

The churches were at the forefront of the struggle for freedom and justice and goodness. They helped to get us here and now continue their good work through being agents of unity and reconciliation, assisting to rehabilitate the moral quality of our society and promoting ubuntu, persuading their members to be ready to forgive, and persuading the beneficiaries of apartheid to be ready to give reparation and assist in the process of transformation for their own sakes, for the sake of their children and for the sake of the future of this rainbow nation.

This raises the following questions:

- How can the Christian church be in the forefront of binding up the wounds of the past, facilitating the healing process, and living as a people and a sign of hope?

- And more specifically and personally: How can that part of the Christian church to which I belong, be in the forefront of this healing process?

The first question as to how the Christian church can be in the forefront of the reconciling and healing process, I attempt to answer under three headings, namely:

- The church's spirituality of reconciliation

- The church's ministry and mission of reconciliation 
- The church's resources for its ministry and mission of reconciliation.

Each of these areas could be subjects for further theological reflection, academic research and practical outworking in the church and in the world.

\section{The church's spirituality of reconciliation}

Spirituality is a word that is commonly used yet difficult to define. Concerning its precise subject matter, many theologians have particular suspicions, some of which are rooted in a long separation between theology and spirituality. This separation has led to the interpretation that the former is concerned with the intellectual, and the latter with the devotional aspects of Christianity. Other suspicions are rooted in spirituality's apparent desire to cross all kinds of disciplinary boundaries; its apparent claims to unlimited recourses (for example, historical, theological, philosophical, psychological, and anthropological); and its inability to define its own methods very precisely.

As a matter of fact, significant attempts have been made by scholars in recent years to provide a coherent definition and methodology from both a theological and historical standpoint. As an area of study and reflection, spirituality is emerging more clearly as interdisciplinary but with a special relationship to theology. It is concerned with the specifically 'spiritual' dimension of human existence. (Sheldrake, 1998:33, 34.)

While it is useful to reach some general definition of the term, especially for the purpose of conversation between faiths and between disciplines, overall, generic definitions have severe limitations. The way we understand the concept is ultimately dependant on quite specific religious perspectives.

In Christian terms, 'spirituality' concerns how people subjecttively appropriate traditional beliefs about God, the human person, creation, and their interrelationship, and then express these in worship, basic values and lifestyle. Thus, spirituality is the whole of human life viewed in terms of a conscious relationship with God, in Jesus Christ, through the indwelling of the Spirit and within the community of believers. As a field of study, 'spirituality' examines this dimension of human existence from a variety of standpoints of which the theological, historical and phenomenological are the most common.

(Sheldrake, 1998:34, 35; italisation - SB.) 
While Christian spirituality embraces the whole of human life lived in "the fellowship of the Holy Spirit" (2 Cor. 13:14b), and has many traditions, Sheldrake (1998:10), maintains that:

... their source [is] in three things. First, while drawing on ordinary experience and even religious insights from elsewhere, Christian spiritualities are rooted in the Scriptures and particularly in the gospels. Second, spiritual traditions are not derived from abstract theory but from attempts to live out gospel values in a positive yet critical way within specific historical and cultural contexts. Third, the experiences and insights of individuals and groups are not isolated but are related to the wider Christian tradition of beliefs, practices and community life. From a Christian perspective, spirituality is not just concerned with prayer or even narrowly religious activities. It concerns the whole life.

In the West, what today is called spirituality, and used to be called ascetical and mystical theology, began as an undifferentiated reflection on Christian sources and their application. From the patristic period until the development of the "new theology" of scholasticism around the twelfth century theology was a single enterprise.

To be a theologian meant that a person had contemplated the mystery of the incarnation and possessed an experience of faith on which to reflect. Theology was always more than an intellectual exercise. Knowledge of divine things was inseparable from the love of God deepened in prayer. For Augustine (De Trinitate, Books XII-XIV), God is known not by scientia but by sapientia - that is to say, not by objectification and analysis but a contemplative knowledge of love and desire. Patristic theology was not an abstract discipline separated from pastoral theory and practice ... Thus, theology was a process, on different levels, of interpreting Scripture with the aim of deepening the Christian life in all its aspects. (Sheldrake, 1998:36, 37.)

Scholasticism could be said to have resulted in a divorce between theology and, what today is called, spirituality. This was not the case in the Eastern Orthodox tradition which:

... continued to follow the patristic model of 'mystical theology'. This synthesised ethics, spirituality and doctrine. Orthodox theology may be defined as a spirituality that expresses a doctrinal attitude. In a sense, doctrine has priority and leads to practice as a natural outcome. Yet, theology itself is inseparable from contemplation and is mystical in that its overall aim is to show forth the divine mystery. True theologians are those who 
experience the content of their theology. On the other hand, mystical experiences, while personal, are nevertheless the working out in an individual of a faith that is common to all. (Sheldrake, 1998:37, 38.)

In recent decades a major shift has taken place in Western theology. This shift "has been from a more deductive, transcultural theology towards serious reflection on experience of God in its particular and plural cultures. In harmony with this shift, and partly provoked by it, understanding of the Christian life have also changed. 'Spiritual theology' has given way to a more dynamic and inclusive concept known as 'spirituality'" (Sheldrake, 1998:55). As a consequence, the separation or divorce noted at the end of the Medieval period and reinforced by the Enlightenment has begun to break down.

Sheldrake makes four observations concerning Christian spirituality.

- Spirituality is not limited to elites, and "has broadened beyond attention to a limited range of phenomena, for example mysticism, to include reflection on the values and lifestyles of all Christians" (Sheldrake, 1998:56). This term has gained ecumenical acceptance "and so studies of it tend to draw on the riches of a shared Christian heritage rather than limit themselves to sectarian understanding of life in the Spirit".

- Spirituality has become more fruitfully associated with mainline theology and Biblical exegesis. "This is associated with a renewed theology of grace and of the human person. In some cases, reflection on experience, and the question of the relationship between experience and tradition, has become the heart of theological method." Interesting to note that the Wesleyan approach to doing theology - or reflecting on Christian sources and applying them - engage the "Wesleyan quadriclateral", namely Scripture, reason, tradition, and experience. "One specific area where there is a fruitful dialogue is in the interrelationship between spirituality and moral theology", now more commonly called ethics.

Nowadays, moral theology focuses more on who people are rather than just being concerned with what they do. Spirituality and moral theology thus find a common language in a renewed theological anthropology and understanding of grace, increasingly acknowledging the basic unity between the moral and the spiritual life. The focus is on what enables a person to become truly human within a commitment to Christ and aided by the action of grace (Sheldrake, 1998:57). 
Yet spirituality and ethics are not totally synonymous. While spirituality, in its widest sense, includes the whole of a person's or group's spiritual experience or orientation, and therefore may include behaviour and the attitudes that underlie it, it cannot be reduced to that.

- Spirituality 'is not so much concerned with defining 'perfection' in the abstract as with surveying the complex mystery of human growth in the context of dynamic relationships with God" (Sheldrake, 1998:58).

- It is never abstract or pure in form but is lived out in a context, and indeed is shaped by that, even as it seeks to reshape or transform that context. Further, that context has become much more fluid in recent decades.

In Christian terms, spirituality, concerns not only some other life but simply human life at depth. What this means arises from what Christian revelation and tradition suggest about God, human nature and the relationship between the two. Christian spirituality derives its specific characteristics from certain fundamental beliefs, e.g. Christianity affirms that human beings are capable of entering into a relationship with God that is lived out within a community of believers sustained by the presence of the Holy Spirit. "Put briefly, Christian spirituality exists in a framework that is Trinitarian, pneumatological and ecclesial." (Sheldrake, 1998:61.)

"The challenge to Christian spirituality [then] is to show how its vision of God may contribute powerfully to the desire to find communion with others, express compassion for others and transform the world." (Sheldrake, 1998:202.)

In 2 Corinthians 5:11-6:2 the apostle Paul speaks of both a ministry and a message of reconciliation. It can therefore be concluded that a ministry of reconciliation presupposes a spirituality of reconciliation. In this respect we are looking at cultivating a spirituality of reconciliation, healing, and transformation in post-apartheid South Africa, which would mean making these a lifestyle rather than a series of programmes or initiatives, yet remaining concrete, practical, and accountable.

Addressing his fellow Anglican bishops at a meeting of the synod of bishops in April 1992, Desmond Tutu (1994:231) while recognising that "the Gospel is almost always disturbing status quos" expressed the hope that: 
... [now] we can have a different emphasis - that of seeking to strengthen the inner life of the church, of pouring oil and balm on wounds, of nurturing our people for the tasks of transformation. This is not being pietistic. It is to cultivate an authentic spirituality of transformation in the transition period of much flux, bewilderment, violence and turbulence.

As stated, cultivating a spirituality of reconciliation (or transformation) would mean making reconciliation a lifestyle rather than a series of strategies, programmes or initiatives, while remaining concrete, practical, measurable and accountable. Whatever the understanding of cultivating a spirituality of reconciliation or transformation means, it would likely include the following aspects.

- Taking the place of the middle cross in order to be a minister of reconciliation. This could include, again in Tutu's words, entering "more deeply into the anguish, desolation and pain in the heart of God to bring before the throne of grace those persons and situations of concern, to hold up for blessing and healing especially those we may think are the perpetrators". That is, the church has a mediation role to fulfil between victims and offenders.

- Identifying with "those persons and situations of concern" and brokenness, and intentionally getting alongside them.

- Weeping with those who weep (Rom. 12:15b), carrying "each other's burdens, and in this way" fulfilling "the law of Christ" (Gal. $6: 2)$. That too, would involve the church in a ministry of presence. Again in Tutu's (1994:232) words: "I personally would want for us, maybe for me, to be spending a great deal more time where people are hurting ... I want to be more present with people where they are ... I don't know why they should think so but when one visits in situations of that kind, people seem to be given a sense that they are important and so it is affirming people and helping in the very difficult, testing time of transition." That too, is part of the church's pastoral ministry, indeed of its apostolic mission to the poor, the prisoners, the blind and the oppressed.

- Listening to the groans of creation, of the nation, of ourselves and of the Holy Spirit (Rom. 8:22, 23, 26), listening to and asking questions without necessarily giving answers, certainly not easy answers, and allowing this to bring us more deeply into the anguish, desolation and pain in the heart of God, and bringing those persons and situations of concern before the throne of grace, for blessing and healing. This would call the church more 
fully into a ministry of intercession, i.e. of standing in the gap between the already and the not yet of God's Kingdom.

- The church must become vulnerable by accepting weakness as a spiritual gift. Perhaps the church needs to explore and practice more fully the implications of God's power "made perfect in weakness" (2 Cor. 12:9b). Perhaps this is at the heart of its ministry of reconciliation, if not its apostolic mission. This too, could be an area for theological reflection, academic research, and practical outworking in the church and in the world for which Henry Nouwen's spirituality could serve as a practical guide.

As discussed in my doctoral thesis, "Who will blow the trumpet? A Christian ethical evaluation of the Jubilee as a hermeneutical tool for reconciliation, healing, and transformation in post-apartheid South Africa" (Barry, 2008), Nouwen offers a spirituality that makes no distinction between the inner and the outer life affecting and effecting the relationship between God, others, and the self. This balance has often been lost between evangelicals and activists in South Africa to the detriment of each other and to the nation as a whole. He offers a spirituality that is integrative, one that holds together the three imperatives of the great commandment (Mark 12:29-33), namely to love God, others, and the self. It is deeply rooted in his understanding of who Christ is, and what he has done, is doing, and can confidently be expected to do in the future. His Christological vision calls for a radical social ethic that is committed to justice and, because it is realistic about human nature, the world and society in which we live, and the sin and brokenness we share, a social ethic that is committed to reconciliation, healing, peacemaking, restoration, and transformation.

Nouwen elicits a Christocentric spirituality that calls us to live with Jesus at the centre. Living with Jesus at the centre means to live in union with the One who is called, and who calls us to live as the beloved of God. To live as the beloved is to find our true identity, sense of belonging and security, meaning, and purpose in the assurance that we are loved, deeply loved, by God. He holds out a spirituality that is deeply personal, but never private, and committed to the gift and the obligation of Christian community, for to live in Christ is to live in community. It is a spirituality that resists both cynicism and pseudo-mysticism, is deeply grounded in Christian hope for the future, and calls for responsible, active, and sacrificial engagement in the present. 
Ironically, Nouwen's is a spirituality that calls us to live with Jesus at the margins of society. To live as the beloved is to live in the certainty of God's love revealed in Christ. This empowers us to live in and to speak to a postmodern world where certainties have failed, or are no longer trusted, without succumbing to the deceptive certainty of an unquestioning and sometimes rabid fundamentalism. It allows for, even calls for, paradox and mystery. It does not offer simplistic answers to the mystery of God's love and justice and human suffering, and while not denying or trivialising these questions, does not see suffering or weakness as obstacles to grace, joy, and peace. Rather, it is a spirituality that invites us to encounter God, to experience God's strength in human weakness, and to reveal God's presence there by living as signs of the Kingdom that is already but not yet here.

Nouwen's is a spirituality with a strong, even a dominant, kenotic ethic, one that is counterintuitive, countercultural, and therefore prophetic. Contemplative certainly, his is a spirituality that is also deeply missional. For Nouwen, contemplation means to see (God), and ministry and mission means to make visible, to and for others, that (God) which is seen.

Such a spirituality promises individual and collective transformation through the free gift of God's grace, yet is one that requires our voluntary, active, participation. Being transformed by grace means allowing ourselves to be shaped or formed by others in community for the sake of others. This calls for many other spiritual disciplines, among them solitude, prayer, service, generosity, hospitality, compassion, caring, friendship, and gratitude. All of these are outward expressions of inner moral values. For Nouwen, the disciplines of gratitude and generosity are at the heart of what it means to live in a community that is called eucharistic. It is also eucharistic in the sense of being called to live life as offering and sacrifice. It is a life of deep intimacy with Christ and costly solidarity with the world he came to save. To live in union with Christ and solidarity with others is to accept being taken (or chosen), blessed (anointed or empowered), broken, and given by God to and for others.

Such an identification calls for an intentional posture of vulnerability that follows Christ in his kenosis, or downward mobility, into the world, and shares in his mission as a wounded healer. This personal, spiritually charged, social ethics of downward mobility is lived out in prayer, resistance, community, receiving the gift of the poor, the suffering, the weak, the broken, the oppressed, and the marginalised, and accepting our own weaknesses and vulnerability as 
spiritual gifts. It is here that we are invited to both find and to reveal the presence of Christ.

Prayer is essentially transformational; a transformation that begins with us as we name and take responsibility for our own sinfulness and brokenness. It involves mutual confession and forgiveness, and communion or intimacy. Prayer summons us to divest ourselves of all illusions of control and power. It calls for both protest and affirmation, and that in the traditional, Biblical language of dying and rising, of taking off the old and putting on the new. It is martyrdom in the sense that we are called to resist self-centeredness in order to affirm Christ-centeredness and other-centeredness. It resists the multiple powers of death, among them warmongering, violence, racism, xenophobia, and the demonising of the other as the enemy. In humility and confession we are called to recognise that the enemy, and that which we hate most, is often within ourselves. Such a spirituality exposes the temptations of power, success, and relevance; it resists the tyranny of pragmatism by reminding us that the right thing to do is always the right thing to do, even if it doesn't seem to work or result in the immediate, desired outcome.

Further, such spirituality resists discrimination on the basis of race, religion, gender, or sexual orientation. It resists the ethics of blaming and retribution. It affirms human dignity, value, worth, freedom, responsibility, and accountability, and expresses itself in an ethics that is people-centred rather than issue-centred. It affirms, indeed celebrates, unity in diversity and diversity in unity. It calls for compassion and humility, and in doing so, it engenders joy.

Compassion is the willingness to share suffering alongside of, with and for others. Humility is the willingness to share a common humanity, and in our context to share, a common sense of being African. Boraine (2008:215) writes:

South Africa needs to rediscover the core meaning of ubuntu if it wishes to continue the process of reconciliation. With crime statistics soaring and a high incidence of violent crimes ... it seems as if ubuntu is a romantic notion that is practiced in the breach. To recognize and to affirm our common humanity in South Africa is essential if our social fabric is not to be torn asunder.

It is a spirituality with an ethics more social than political, and one that is committed to non-violence. Above all, Nouwen offers a spirituality that is committed to Christian community and to spiritual and moral formation within that community, despite its own conflicts, 
divisions, frustrations, and brokenness, as well as its own need for forgiveness, reconciliation, mediation and unity.

By staying in touch with these very weaknesses we can connect with the God of grace who became vulnerable in Christ, the God whose power is made perfect in weakness (2 Cor. 12:9b). To live in Christian community is to:

- live in mutual accountability, confession, and forgiveness;

- accept others' and our own brokenness as spiritual gifts;

- be formed in and through worship and prayer (liturgy);

- live in gratitude, generosity, and hospitality, and to discover that hospitality (the gift of giving sacred space to others) is the gift of healing; and to

- live with Jesus at the centre and at the margins.

To live in Christian community is thus to discover the grace of empowered vulnerability, the grace that calls us to be a healing, reconciling, restoring, transformed, and transforming community. We respond to this call not by denying our own woundedness or our past (whether as wounded victims or wounding offenders), but by acknowledging it, taking responsibility for it, and learning from it, ever confident in God's redeeming grace.

The Biblical concept of the year of jubilee is, among other things, about moral restoration by proclaiming kingdom values. This is surely more than, but most certainly can include, programmes of moral renewal for every section of South African society. As Vorster (2007:262) reminds us:

[W] hat is also required is a correct attitude among citizens. Social processes cannot succeed if they are not carried [out] by honest, committed people. Good intentions can easily go astray when people are not willing to serve the bigger purpose. This attitude is lacking. Crime, corruption, sexual immorality, power abuse, exploitation and poverty still plague society and blemish the positive results [following South Africa's transition to democracy in 1994] ... Churches should play an important part in the development of a new attitude. And what is better than pointing to the example of the attitude of Christ? This is the reason why the positive influence that the churches can exert in South Africa's new Liberal Democracy can hardly be overestimated. 
For the Christian community to blow the jubilee trumpet, proclaiming "the year of the Lord's favour" (Luke 4:19) means more than initiating and facilitating such programmes. It means a radical commitment to following Jesus and the kenotic lifestyle he modelled in servanthood and sacrifice. My conviction is that Nouwen (among others) is a reliable spiritual guide or companion who can help us restore moral values by the development of a spirituality of reconciliation, healing, and transformation relevant to South Africa.

\section{The church's ministry and mission of reconciliation}

From the perspective of the Johannine gospel, the writer understands that, just as the Father entrusted Jesus with a mission in the world, so too Jesus entrusts his followers with a mission in the world (John 20:21). How the church understands its apostolic mission in general, will determine how that is undertaken in the specific South African context, and what it means to "be in the forefront of this healing process" of reconciliation, peace-making and nation building. At least two questions emerge concerning the Christian community's apostolic mission:

- What is our mission? and

- Who are the recipients of our mission? (To whom are we sent?)

Among the answers to these questions are the following:

- The church's mission is to proclaim the good news of God's Kingdom breaking in upon us; it is the proclamation of "the year of the Lord's favour" (Luke 4:19). According to the Lucan gospel, Jesus clearly understood his mandate in terms of proclaiming a jubilee year, that is a year of release, restoration and return, of "a new covenant - not of the letter but of the Spirit; for the letter kills, but the Spirit gives life" (2 Cor. 3:6), and of "the ministry of reconciliation ... We are therefore Christ's ambassadors" (2 Cor. 5:18-20).

- The church's mission is to hold out the hope of God's Kingdom (which is understood as creation healed and being healed) coming in its fullness and to live in prophetic anticipation of that.

- The church is anointed to proclaim this good news to the poor, the prisoners as freedom, the blind as sight, and the oppressed as release or liberation, i.e. in terms of "the year of the Lord's favour", the year of jubilee (Lev. 25:8-54; Isa. 61:1-11; cf. Luke 4:14-21). 
It is interesting and challenging to note that in the case of prisoners, the blind, and the oppressed, the good news is specified and takes the form of tangible, concrete and practical changes to their circumstances, but in the case of the poor, the nature of that good news is unspecified. It is therefore part of the mission of the church, to discern what form that good news might, could, or should take in its given context.

\section{The church's resources for its ministry and mission of reconciliation}

The church's primary resource is the gift, presence and power of the indwelling Holy Spirit. According to the Pauline corpus, the ascended Christ has given gifts to all his people to fulfil his, and by extension, their mission on earth.

It was He who gave some to be apostles, some to be prophets, some to be evangelists, and some to be pastors and teachers, to prepare God's people for works of service, so that the body of Christ may be built up, until we all reach unity in the faith and in the knowledge of the Son of God and became mature, attaining to the whole measure of the fullness of Christ. (Eph. 4: 11-13.)

Among the church's resources therefore, are its prophetic, evangelical, and pastoral ministry, as well as its teaching ministry.

The other resources are the church's liturgical and sacramental life, the ministry of presence and healing its people, and its commitment to social justice.

\subsection{The prophetic ministry of the church}

The church's prophetic role is to speak and enact the values, priorities and goals of the kingdom of God within its given political, social and economic context. This involves the church participating fully and responsibly at a national level, but always remembering that participation doesn't mean acquiescence to the status quo. It involves comforting the afflicted, "afflicting" the comfortable, developing and providing leadership and solidarity with the poor (Hay, 1998:153). It means making an intentional option for the poor and marginalised, and not identifying with structures of power and wealth. It means exploring the appropriate, relevant and practical implications of the year of jubilee in the South African context, especially in terms of restoration. This could include the restoration of land, dignity, responsibility and productivity, African culture and 
spiritual heritage, and ecological responsibility in caring for God's creation.

Vorster (2004:285), drawing on De Gruchy (1997), states that part of what it means for the church to remain true and faithful to its prophetic vocation, is a critical solidarity involving three touchstones, namely the church should take sides with the poor and all who remain oppressed; always defend human rights; and be self-critical if it wants to be credible in the eyes of the community at large. Critical solidarity is therefore a valuable definition of the prophetic role of the church, especially at a time of transition. It is here that the recommendations of the TRC to the churches need to be evaluated and implemented.

\subsection{The evangelical ministry of the church}

The church's ministry in the specific context of binding the wounds of the past, crime, and violence, is to ensure that victims, offenders, and their communities are objects of holistic evangelism. This will mean proclaiming the good news of God's forgiving, redeeming, healing, and transforming love.

This has to be done in a way that victims can see the future in terms of healing and wholeness, of which forgiveness may be a necessary part; offenders also must be enabled to take responsibility for their actions, make amends and also see the future in terms of reintegration into society, and the building of holistic relationships. This will involve the Biblical dynamic of metanoia, repentance. Communities can support victims, help reintegrate offenders, build relationships, and prevent or reduce recidivism.

Some of the practical, measurable and accountable ways in which the Christian community could mobilise its resources may be

- to provide a safe environment that will help victims and offenders to grow, learn, tell their stories, forgive, be forgiven, and find strength;

- to promote the principles and practices of restorative justice, e.g. by gathering for reflection, prayer and action, by promoting workshops, rallies, and liturgies that bring crime and justice issues into corporate worship; and

- to work together with other agencies, both government and NGOs, especially with restorative justice initiatives and diversion programmes, one of which, the Fig tree project, is outlined below. 


\subsubsection{The Fig tree project}

The overcrowded conditions in South African prisons, the high recidivism rate of $87 \%$, and the crime-university effect prison sentences have on juveniles in particular, has brought about a realisation for the need of an alternative system to prison sentences, i.e. that of diversion, where the judiciary are offered an alternative to prison sentences for juvenile offenders. Similarly, the high incidence of juvenile offending behaviour, often originating at home, finds expression in school, and results in expulsion. This can be avoided if school bodies are offered an alternative.

Parakletos, now incorporated into Prison Fellowship South Africa (PFSA), was approached in July 2003 by the then presiding bishop of the Methodist Church of Southern Africa, Rev. Mvume $\mathrm{H}$. Dandala, to explore two diversion programmes that have been operating with measured success in Hong Kong since 1999. These are Operations Phoenix and Dawn. These were formulated after researching juvenile offending behaviour in six pacific-rim countries (Lee \& Lee, 2003:114-140).

Grobler and Barry (2006) were able to visit Hong Kong in 2005 in order to conduct the said research. Since then, PFSA - recognised as a leader in crime-care within the restorative justice fraternity, and well respected for its contributions to reconciliation, healing, and transformation - has adopted and adapted lessons learned from the two models, and developed a contextual diversion programme/ juvenile crime intervention for South Africa. This programme has been provisionally named the Fig tree project. A Scriptural foundation for the project and title is found in the parable told by Jesus, which illustrates a twelve month intervention aimed at saving a fruitless tree from destruction.

A man had a fig tree, planted in his vineyard, and he went to look for fruit on it, but not find any. So he said to the man who took care of the vineyard: 'For three years now l've been coming to look for fruit on this fig tree and haven't found any. Cut it down! Why should it use up the soil?'

'Sir,' the man replied, 'leave it alone for one more year, and I'll dig around it and fertilise it. If it bears fruit next year, fine! If not, then cut it down'. (Luke 13:6-9.)

The concept and project has been favourably received by representatives of the Departments of Justice, and Correctional Services, 
the Restorative Justice Centre, Pretoria, and the National Initiative Against Overcrowding in Prisons.

The facilitation of a pilot programme started in the Vaal Triangle area in October 2008, and currently hosts the participation of 72 children. This has taken the form of a partnership between PFSA, Prison Fellowship International (PFI), and SASOL. The project is outlined below.

\subsubsection{Purpose of the project}

The rehabilitation of youth-at-risk. The principal goal is to eliminate deviant and unlawful behaviour, and to work towards reconciliation and reintegration with the local community.

\subsubsection{Project structure}

The project is structured according to the following basic components:

- Each participant is assessed and a plan of intervention is agreed upon where strategic partners in psychology, welfare, substance abuse, and counselling are involved on an individual needs driven basis.

- Groups of around 25 participants are formed into a class. They attend an eight week foundational programme of two hours per week. This programme focuses on transformation, restoration, reconciliation, and development of individual potential, including leadership skills.

- Support groups are formed around each participant, and positive activities are encouraged. These may include community service, sports activities, social events, skills, and academic development. These are determined by advised choice and availability within the community.

- After completion of the foundational programme, monthly meetings are held, at which experiences are shared and individuals are held accountable to the group.

- Individual and group counselling sessions continue.

- Participants are encouraged to enrol in courses and positive activities presented by churches and elsewhere in the community. All are encouraged to participate in community service and other activities aimed at community upliftment. 
- An activity weekend is arranged to develop problem solving, conflict resolution, and leadership skills.

- Where the need is identified, participants' parents are involved in group sessions.

- Monthly group sessions continue, until a final assessment is made at the end of the year. Based upon this, a report is compiled and sent to the referring body. Participants are encouraged to continue attending the monthly sessions.

- Participants of earlier classes are equipped to facilitate, support, and coordinate activities and meetings.

- Meetings are held with parents where parenting skills are developed and problems discussed. At the outset, they are asked to commit themselves to supporting the referred juvenile, and guidelines are supplied.

\subsubsection{Termination of participation}

Participation may be terminated in one of four ways:

- Those identified by the project director(s) as non participative, uncooperative, or disruptive, may be directed to the referring body for their reassessment.

- Those who wish to withdraw from the project, will be reassessed by the referring body, who may decide to continue with the interrupted prosecution or other disciplinary action.

- Those who have completed the project, will be commended to the referring body, along with a full report.

- Those who, according to the opinion of the project director(s), have made sufficient progress to warrant early release from the project, will be commended to the referring body, again with a full report.

\subsubsection{Expected outcomes of the project}

The Fig tree project focuses on strengthening the participants' belief in the moral validity of rules, activating their commitment to social values and norms, revitalising their involvement in conventional activities, encouraging their attachment to conventional others, while discouraging their attachment to delinquent peers. 


\subsubsection{Benefits}

The main benefits inherent in implementing the project are:

- Individual and family counselling services: By therapeutic intervention, the participant's coping capacities in relating to their family, school, peers, and vocational systems are enhanced.

- Volunteer and community service: By providing opportunities for the participant's coping capacities in relating to their family and marginalised in the community, their life experiences are enriched.

- Groups and activities: By enhancing the participant's social skills, interpersonal relationships, and life aspirations, their undesirable attitudes and behaviours are modified.

- Adventure programme: By exploring their potential through accomplishing some command and problem-solving tasks, the participants' self-confidence in boosted.

- Parental work: The parents involved are equipped with specific knowledge and skills to cope with the situation confidently.

\subsubsection{Beneficiaries and their specific rolls}

To benefit from the project, stakeholders are required to be active, not passive, and therefore have specific roles to fulfil.

- Youth-at-risk: Their voluntary participation and cooperation is required.

- Parents and families: In addition to their voluntary participation and cooperation, they are required to support the participant, and provide a supervisory and accountability structure.

- Local community: By their voluntary participation and cooperation, they support, encourage, and reinforce the efforts of the participants in rehabilitation, reconciliation, and reintegration.

- Schools: Their voluntary participation and cooperation in referring participants, making time and venue accessible to the pupil participants, they support, encourage, and reinforce their efforts to make things right.

- Judiciary: By endorsing the project, and referring individuals, they too support, encourage, and reinforce the participants' efforts to make things right. 
- Department of Correctional Services: By hosting reality contacts in the form of exposure to life in prison, and encouraging exoffenders to share their experience of crime, prison, and reintegration, they assist in breaking through the barriers of denial.

- Government: The promotion and establishment of restorative justice practices such as this diversion project are important roles of government.

- South African Police Services: By their voluntary endorsement, participation, and cooperation in referring individuals, they too support, encourage, and reinforce the participants' efforts to make things right in a restorative as opposed to retributive environment.

The participants are 14-18 year olds who have committed petty crimes. Instead of expulsion, prosecution, or a possible prison sentence, they are referred to the programme on a voluntary basis. As well as judicial referral, referrals may also be made by schools, community organisations and parents. Individuals may also refer themselves.

This project is based within the community. The local church is equipped and empowered to act as facilitators, thus becoming part of the solution in addressing crime. Crime-care is thus seen as a partnership between local community and government agencies, and this, in terms of restorative justice principles.

\subsection{The pastoral ministry of the church}

The church's pastoral ministry could involve putting into place structures for victim offender mediation and reconciliation. It could also involve becoming agents for peace and reconciliation initiatives. Victim offender conferencing (VOC) is a restorative justice means to this end, which the church could adopt and adapt with Christian integrity. An example of such a Christian programme is Prison Fellowship International's Sycamore tree project (STP) currently conducted by crime-care ministries in the following countries: Australia, Cayman Islands, Colombia, Costa Rica, England, Hong Kong, Hungary, Kenya, Korea, Netherlands, New Zealand, Northern Ireland, Panama, Philippines, Rwanda, Scotland, South Africa, USA and Wales.

In South Africa, the first STPs were piloted by the Prison Fellowship South Africa (PFSA) Free State and Vaal Triangle region in Leeuhof and Groenpunt centres of correction in 2005/2006 respectively. 
Subsequently, PFSA has partnered with the Department of Correctional Services to implement the STP in all prisons throughout South Africa. By December 2007, this programme had been implemented in 35 prisons in three provinces: Gauteng, Western Cape, and Free State. The Sycamore tree project is outlined below.

\subsubsection{The Sycamore tree project}

The Sycamore tree project (STP) is an intense, short-term project that facilitates the mediation process between victims of crime and offenders in an attempt to bring about reconciliation, restitution and reparation. This is done by awareness raising, recruiting and training volunteers to mediate between victims and offenders. The victims and offenders are not related, that is, the victims are not the particular victims of those offenders.

The Sycamore tree project is about a voluntary journey where, together, victims and offenders discover the Biblical principles of responsibility, confession, repentance, forgiveness, and reconciliation. The name comes from the account in Luke, of the corrupt tax collector named Zacchaeus, who climbed a sycamore tree to get a better view of Jesus as he walked through Jericho.

Jesus entered Jericho and was passing through. A man was there by the name of Zacchaeus: he was a chief tax collector and was wealthy. He wanted to see who Jesus was, but being a short man, he could not, because of the crowd. So he ran ahead and climbed a sycamore-fig tree to see him, since Jesus was coming that way.

When Jesus reached the spot, he looked up and said to him, 'Zacchaeus, come down immediately. I must stay at your house today.' So he came down at once and welcomed him gladly.

All the people saw this and began to mutter, 'He has gone to be the guest of a sinner.'

But Zacchaeus stood up and said to the Lord, 'Look, Lord! Here and now I give half of my possessions to the poor, and if I have cheated anybody out of anything, I will pay back four times the amount.'

Jesus said to him, 'Today salvation has come to this house, because this man, too, is a son of Abraham. For the Son of Man came to seek and to save what was lost.' (Luke 19:1-10.) 
As a result of this encounter with Jesus, Zacchaeus was transformed. The transformation was evidenced in the community by his acts of reparation, as he paid back four times the amount he had stolen from the local taxpayers, and gave away half his wealth to the poor.

Drawing on Christian and restorative justice principles, the project brings together small groups to talk about their experiences of crime. Although both the foundation and facilitators of the programme are Christian, there is no requirement that participants be Christian, so long as they are willing to be involved in such a programme. (In two programmes facilitated in the Vaal Triangle, a participant from the Islamic faith joined the group with measurable success.)

All participants are asked to agree to some basic standards of conduct, namely to attend all sessions; to be punctual; to participate in the discussions and activities; to listen to each other without interruption or condemnation; to show mutual respect; to keep confidentiality; to be as honest as possible; to stay focused; and to participate in an act of closure, which may include some form of restitution.

\subsubsection{The benefits for victims}

They are given, often for the first time, an opportunity to talk about and reflect on the offence committed and its impact on their lives, and they are more fully informed about crime, offenders, and restorative justice. This is done by exploring Biblical concepts of repentance, forgiveness, and reconciliation; telling their stories to convicted prisoners; and hearing prisoners begin to take responsibility for their actions.

In many cases, this has helped victims to experience closure and peace, and even to experience salvation or Christian growth, and in some cases, even a support for and involvement in prison ministry.

\subsubsection{The benefits for offenders}

They too are given the opportunity, often for the first time, to understand the results of crime on victims and the community; to agree to take responsibility for their actions; and to begin making amends by taking part in an act of symbolic restitution.

As with most victims, many prisoners have experienced salvation or Christian growth as a result of the project and in some cases, exoffenders have themselves become involved in prison ministry e.g. 
Joseph Nyembe, who after release from prison, became involved in prison ministry, and is currently serving as a director on the Board of Prison Fellowship South Africa (PFSA).

\subsubsection{The benefits to the community}

Interested, affected parties are given the opportunity to become directly involved in responding to crime by providing support to victims; by holding offenders accountable; by assisting with their rehabilitation and reintegration; by building relationships; and by helping to reduce recidivism and prevent crime.

The project is located both within correctional centres and the community. It is run over a period of eight weeks with one two-hour session per week as follows:

\begin{tabular}{|l|l|l|}
\hline Session & Topics & Objectives \\
\hline Session 1 & Introduction & $\begin{array}{l}\text { To prepare offenders and victims to } \\
\text { participate in the project. }\end{array}$ \\
\hline Session 2 & What is crime? & $\begin{array}{l}\text { To explore what the Bible says about } \\
\text { crime. }\end{array}$ \\
\hline Session 3 & Responsibility & $\begin{array}{l}\text { To understand what it means to take } \\
\text { responsibility. }\end{array}$ \\
\hline Session 4 & $\begin{array}{l}\text { Confession and } \\
\text { repentance }\end{array}$ & $\begin{array}{l}\text { To understand the meaning, im- } \\
\text { portance, and power of confession } \\
\text { and repentance. }\end{array}$ \\
\hline Session 6 & Restitution & $\begin{array}{l}\text { To understand the meaning, im- } \\
\text { portance, and power of forgiveness. }\end{array}$ \\
\hline Session 7 & Towards reconciliation & $\begin{array}{l}\text { To understand restitution as a re- } \\
\text { sponse to crime. }\end{array}$ \\
\hline Session 8 & Celebration & $\begin{array}{l}\text { To move towards healing and res- } \\
\text { toration by sharing letters and } \\
\text { covenants. }\end{array}$ \\
\hline
\end{tabular}

After an initial year of implementation in 2007, the Department of Correctional Services has confirmed its intention to see STP established in all prisons throughout South Africa. The impact of STP in South Africa cannot yet be measured, but perhaps the most fascinating use of the programme within the African context, has been in the facilitation of the reconciliation process between the 
Hutus and the Tutsis in Rwanda. Here the programme is called The umuvumu tree, after a local tree well known for its healing properties.

The formation of a partnership between PFSA, Prison Fellowship International (PFI), and the International Prison Chaplains Association (IPCA) in March 2008, has as its focus the promotion and establishment of restorative justice practices throughout Africa. For this purpose, STP has been identified as the chosen means, as it lends itself to facilitation by meagrely resourced and basically trained teams. Although STP's demand for resources is minimal, it has accredited itself as having an effective outcome, as its performance in Rwanda, and more recently Kenya, confirms.

Seeking other pastoral responses, the C.B. Powell Bible Centre at the University of South Africa, Pretoria, in 2002, in cooperation with Tshepo Network, a Radio Pulpit community building initiative hosted a series of workshops on different aspects of prison ministry. The papers presented were published in 2003 (Swanepoel, 2003).

Swanepoel (2003:105-126) outlined the following practical suggestions for evangelical and pastoral involvement in his presentation:

- Contact ministries

- Friendship ministries: evangelical, supportive, and logistical

- Preaching ministries: evangelical, discipleship, and focused on addressing holistic needs

- Discipleship ministries: establishing and developing the church in prison through small groups

- Specific goal ministries: KAIROS, Alpha, and EE III, all actively involved in prisons throughout South Africa

- Training ministries: skills development and education

- Pastoral counselling ministries: indicated as the greatest need during a combined UNISA/DCS survey (2002)

- Group work that includes: Bible study, support, prayer, evangelisation, fellowship, training, and discussion groups focusing on relationship and personal issues such as family life, friendship, work, self image, loneliness, discipleship, loss, conflict, money matters, depression, substance abuse, sexuality, gangs, and HIV and AIDS 
- Support ministries

- Correspondence ministries: encouragement ministry through letter writing

- Correspondence training programmes/courses

- Prayer ministries

- Financial empowerment ministries:

- Financial support for ministries

- Financial support for prisoners, ex-offenders, victims, and families

- After care ministries;

- Ministry to those inmates preparing for release and reintegration

- Ministry to the community/church in preparation for offenders' release into that community/church

- Ministry after release; this could include support groups, halfway houses, vocational training, and social skills development

- Ministries to victims: e.g. a holistic trauma response and support centre, supported, staffed, and resourced by a collaboration of government, churches, NGOs, and other community support groups

- Ministries to families of victims and offenders

The crime situation in South Africa is often experienced as so overwhelming as to be debilitating, often resulting in a fatalistic resignation to despair and inactivity. It is important therefore, to awaken individuals and leaders within the faith community, to the immense range and diversity of possible involvement, thus placing the Body of Christ in the forefront of the healing process of reconciliation and transformation.

Prison ministry [and by extension, to all people affected by crime and violence] is an important ministry. It is a challenging ministry. It is a demanding ministry. It can be a rewarding ministry. Every local church and every Christian is called to be actively involved ... in some way or another. If we really work together we can make a difference not only to the crime rate, but more importantly, to the lives of many people and most 
importantly, to the kingdom, the glory and honour of God. (Swanepoel, 2003:126.)

\subsection{The teaching ministry of the church}

The church's ministry of teaching is perhaps one of its greatest resources in engaging people in the transforming values, priorities and goals of the kingdom of God. The church has a vital role to play in education - in its literal sense of leading out and leading towards - and this task will engage the ministries of prophecy, evangelism and pastoral care, as well as the church's liturgical and sacramental life.

Practical outcomes of this could be seminars and workshops focusing on reconciliation and related issues, e.g. the relationship between justice, forgiveness, reconciliation and reparation. It could also involve training and equipping leadership at the local level, as well as theological students, in the skills required for ministries of: reconciliation, trauma counselling, victim offender conferencing/mediation, conflict resolution, and crime-care to all those affected by crime.

Vorster (2007:260) suggests that preaching can fulfil an important role by mens of the followinig:

- revealing the moral principles and norms of the kingdom of God basically, preaching should shape Christians into servants;

- teaching Christians how to build the nation, by fostering repentance and forgiveness, and by reminding people of all races that unity and harmony is the way to peace;

- defining the moral foundations for a responsible redress of society's social inequalities, i.e. land restitution, affirmative action, political protest, labour relations, business, religious freedom, and HIV and AIDS prevention;

- nurturing respect for human rights, especially those of women and children - the most common victims;

- revealing the God-given foundations of responsible family life and sexuality; and

- being politically relevant by being in dialogue with other roleplayers in the socio-political field. 


\subsection{The liturgical and sacramental life of the church}

At the centre of the church's liturgical and sacramental life is the holy communion (eucharist). This is an invitation to remember, to be reconciled, forgiven, be healed, to find hope, and to celebrate life together (1 Cor. 11:26).

The church gathered as eucharistic community is itself a microcosm of the nation; it is a paradox reminding us who we are, and what we are called to become, i.e. broken yet whole, divided yet one, and sinful yet holy. The eucharist reminds us that, Christlikeness is both a process and a goal. Therefore, at a national, regional and local level, the church can promote reconciliation and healing by creating appropriate liturgies, utilising the themes of the Christian year e.g. advent, lent, Good Friday, easter and Pentecost, and celebrating and proclaiming reconciliation and unity.

Vorster $(2007: 261,262)$ further proposes the following broad guidelines for the church gathered as worshipping community:

- Praying for the poor and for a Christian response to poverty;

- reminding Christians of their calling to be involved in addressing and being part of the solution to social problems;

- celebrating the sacraments in such a way that highlights the plight of the marginalised, especially abused women and children;

- expressing the unity of the Christian community in such a way that it brings hope to a society reeling under the impact of racism, xenophobia, and ethno-centrism;

- accentuating the Christian virtue of sharing against the background of the current policies of land reform and affirmative action;

- drawing attention to the importance of family life and the value of stable families for society at large;

- focusing attention on the HIV and AIDS pandemic, its impact on those infected and affected, and the sin of rejection and stigmatisation;

- welcoming people with a same-sex orientation, while guiding them towards a Christian expression of their sexuality; and 
- encouraging one another to live with the attitude of Christ - one characterised by servanthood and sacrifice.

The worship service can function as a generating station where the energy for social change can be created. Christians can be the carriers of this energy to the secluded regions of society where people live in the darkness of despair. Worship should move people to seek solutions (Vorster, 2007:262; italisation - SB).

The church might explore how the Lord's Table could itself become a sacred and safe space, for bringing people together, to name the breach and offer bread to one another as a sign of journeying together towards forgiveness, reconciliation, peace and healing. Liturgically, bringing together the past, the present, and the future, the eucharist is itself process and goal, a means to the end, which is the kingdom of God.

\subsection{The church's ministry of presence}

This can be understood in a number of ways and at a number of levels.

- Making South Africa, and in fact, Africa our home, by embracing the former and intentionally connecting with the latter. This could involve exploring black and African theology and seeking rapprochement with African Independent Churches (AICs). Seeking to embody the kingdom of God in Africa could mean listening to and taking seriously the voices of discontent, and struggling to reconcile the ideal with the fallacy of the rainbow nation. One particular area of engagement with the AICs could be in the area of holistic healing.

- Being a local church, i.e. being the Body of Christ in a particular context and culture, and promoting and celebrating reconciliation proper to that context.

- Offering the traditional ministry of sanctuary, i.e. a sacred and safe place for people to tell their stories, to intentionally enter the process of reconciliation, especially where its necessary preconditions are metanoia - repentance and confession, forgiveness, doing justice and making reparation, and to discover a locus of meaning, healing and hope. 


\subsection{The church's ministry of healing}

It is ironic that in exploring the church's resources for reconciliation, healing, and transformation, the church's explicit ministry of healing, does not immediately offer itself, and is easily and often overlooked. There is therefore a need for rapprochement between mainline, AICs, and charismatic and pentecostal churches to explore the theology, or theologies, of healing, the practical implementation of such ministries, as well as the dangers of divorcing practice from theology. This offers itself as fertile, contextual challenges for further research.

\subsection{The people of the church}

Being a microcosm of the nation, the people of the church, can provide a place for story telling, by black and white, young and old, and rich and poor. They are given an opportunity to tell their stories, hear, understand and hopefully, find one another. Storytelling, perhaps more than confrontation, has the power to engage people passionately and compassionately in practical responses to poverty, crime, violence and other forms of inhumanity as well as the HIV and AIDS pandemic.

\subsection{The church's commitment to social justice}

Finally, the church has a commitment to social justice, and this commitment is worked out in and through its other ministries of prophecy, evangelism, pastoral care, teaching, presence, and healing, and in its common life and witness expressed in liturgy and sacraments.

\section{A particular and personal journey: from local churches' initiative to national and international para- church organisation}

The second question raised in the introduction, i.e. how can that part of the Christian church to which I belong, be in the forefront of this healing process. I propose attempting to answer this by offering the story of a particular and personal journey: from local churches' initiative to national and international para-church organisation.

The conference of the Methodist Church of Southern Africa in Johannesburg on 30 August 2005 adopted The Charter of the Mission Congress (held in Umtata in November 2004) which stated: God has given us the vision of "A Christ-healed Africa for the healing 
of the nations", and challenged its members "to share more deeply God's passion for healing and transformation". The words for healing and transformation, which the MCSA had been using for some time, had earlier been incorporated into the mission statement of my own local church, the Three Rivers Methodist Church, Vereeniging, namely: Calling, equipping and sending disciples of Jesus Christ for healing and transformation.

As a local church we entered into a partnership with other local churches, including Afrikaans-speaking churches, in the Vaal Triangle, and in 2001 initiated a crime-care ministry called Parakletos. A former policeman and transformed apartheid law enforcement officer, Douw Grobler, was appointed as mission pastor to initiate community involvement in crime-care. The long-term vision of Parakletos was to minister to victims of crime and violence (and their families), offenders - both awaiting trial and sentenced - in correctional facilities (and their families), and members of the uniformed services, especially the Department of Correctional Services (and their families).

Guided by evangelical and pastoral concerns, and later by restorative justice principles, Parakletos - as the name suggests saw itself as being called alongside all the major players affected by crime and violence, namely victims, offenders and the wider community. In the five years that it was operating, its focus tended largely - but not exclusively - to be on prison ministry, and this mainly due to restrictions on human and financial resources.

Early in 2005, Parakletos was invited to become partners in the revival of Prison Fellowship South Africa (PFSA), now one of 116 national ministries chartered as members of Prison Fellowship International. PFI is a global organisation of independent national bodies committed to working together in reaching out to prisoners, ex-prisoners, victims, related families, and others affected by crime. Established in 1976 by former White House aide Charles Colson (of Watergate fame and infamy), PFI has grown from a prison ministry to become a holistic crime-care ministry, and into the largest such ministry in the world. Its vision statement reads:

To be a reconciling community of restoration for all those involved in and affected by crime, thereby proclaiming and demonstrating the redemptive power and transforming love of Jesus Christ for all people.

Its mission statement reads: 
To exhort and serve the Body of Christ in prisons and in the community in its ministry to prisoners, ex-prisoners, victims and their families, and in its advancement of Biblical standards of justice in the criminal justice system.

PFSA's vision is to be a reconciling community for all, thereby rehabilitating those who have offended society, and assisting with their reintegration into the community through the proclamation and demonstration of ubuntu and the love of God.

PFSA, now totally incorporating Parakletos, finds itself under the leadership of Douw Grobler, appointed as executive director, steadily growing in its vision to be functional in all of South Africa's nine provinces. More recently, and in partnership with the Departments of Correctional Services and of Justice, the Restorative Justice Initiative of Southern Africa, the business sector, represented by SASOL, and some international donors (facilitated by PFI), PFSA has been piloting the implementation of juvenile offender diversion programmes, in particular, the Fig tree programme as discussed above.

In an attempt to promote both the principles and practices of restorative justice, as a Christian ethical response to healing relationships affected by offending behaviour, thus doing justice, and to motivate and resource local churches in taking responsibility for placing themselves in the forefront of the reconciliation, healing, and transformation process, the Restorative Justice Centre and PFSA partnered with the South African Council of Churches (SACC) in April 2008. The aim of this partnership is to compile a DVD-based facilitation of Bible studies focusing on Biblical justice and the foundation it offers restorative justice, presentations on restorative justice, practical suggestions and guidelines for local church involvement, and a listing of restorative justice practitioners and other resources offered to the local church.

It was hoped that this resource would be completed for timely distribution by the SACC to its members and others, for use as a resource in and around South Africa's Day of Reconciliation on 16 December 2008 and thereafter. This deadline has now been shifted to 2009.

The funding for this resource is a gift of the Mennonite Christian Community in North America. This is yet another example of foreign investment in South Africa's future, and it is hoped that, as the movement gains momentum and the benefits of a reconciled, 
healed, and transformed nation becomes evident, such investments, resources, and initiatives will promote generosity, involvement, and ownership from within South Africa.

This article echoes the hope of Desmond Tutu that the churches will be in the forefront of this healing process which is probably going to proceed for decades and is offered as a resource to that end.

\section{Conclusion}

In conclusion, the church can be in the forefront of this healing process of reconciliation, transformation, peace-making, and nation building by:

- cultivating an appropriate spirituality that makes this a lifestyle rather than a series of strategies, programmes or initiatives, yet remaining concrete, practical, measurable and accountable;

- continuing to challenge injustice, especially economic injustice in general, and to call for changes in legislation to close the gap between rich and poor, and in particular, to challenge the disparity of income between its people, and between its clergy;

- educational programmes including preaching, teaching, training, equipping, small groups, and the use of liturgy as means of personal and community transformation;

- facilitating the networking between the needs and the resources with regards to providing job-training and placement facilities;

- promoting the principles and practices of restorative justice as a Christian ethical response to healing relationships affected by offending behaviour, thus doing justice;

- promoting the principles and practices of restorative justice in order to influence the criminal justice fraternity, and to ensure that crime and legal disputes are addressed fairly, quickly and guided by the values of human relationships;

- providing sanctuary - a safe place, as well as mediation and counselling facilities for victims and perpetrators of offending behavior;

- active holistic evangelism, pastoral care and spiritual formation programmes in prison;

- providing pastoral support for ex-offenders, and building a bridge between the church in prison and local church experiences of life 
in Christ. In order to facilitate this integration, the local church frequently needs to be challenged to transform its own perspective, by becoming the bridge, thus witnessing to the unity of the Body of Christ; and

- networking with other organisations in order to draw alongside all the stakeholders - victims, offenders and communities - supporting and encouraging them to take responsibility, make amends, reintegrate, build relationships, and prevent or reduce recidivism.

Much of the above finds endorsement in proposals offered by the US Catholic Bishops' Conference of 2007 concerning the role of the church in addressing issues related to crime, namely to the following:

- Teach right from wrong, respect for life and the law, forgiveness and mercy

- Stand with victims and their families

- Reach out to offenders and their families, advocate for more treatment, and provide for the pastoral needs of all involved

- Build community

- Advocate policies that help reduce violence, protect the innocent, involve the victims, and offer real alternatives to crime

- Work for new approaches

Some of the above can be achieved by individual local churches, but the more challenging and demanding areas would call for collaboration or networking to form ecumenical and other partnerships across the rainbow nation. Such networking could resource the church to meeting these challenges both quantitatively and qualitatively and in itself could accelerate the healing process.

\section{List of references}

BARRY, S. 2006. Reconciliation: the South African Truth and Reconciliation Commission's contribution to dealing with the past, reconciling and building the nation. In die Skriflig, 40(4):691-714.

BARRY, S. 2008. Who will blow the trumpet? A Christian ethical evaluation of the jubilee as a hermeneutical tool for reconciliation, healing, and transformation in post-apartheid South Africa. Potchefstroom: North-West University. (Doctoral thesis.)

BORAINE, A. 2008. A life in transition. Cape Town: Struik.

GROBLER, D. \& BARRY, S. 2006. The fig tree project: a juvenile crime intervention. Sasolburg: PFSA. (Unpublished.) 
HAY, M.O. 1998. Ukubuyisana: reconciliation in South Africa. Pietermaritzburg: Cluster.

HOLY BIBLE. 1999. New International Version. Cape Town: Bible Society of South Africa.

LEE, F.W-L. \& LEE, K-M. 2003. Effectiveness of community-based intervention of young offenders. Asia pacific journal of social work, 13(2):114-140.

SHELDRAKE, P. 1998. Spirituality and theology: Christian living and the doctrine of God. (In Sykes, S., ed. The trinity and truth series. London: Darton, Longman \& Todd. p. 33-64.)

SWANEPOEL, F. 2003. Everyone can do something: the local church can be actively involved in various ways. (In Swanepoel, F., ed. Prison ministry: the new challenge. Pretoria: Unisa. p. 105-126.)

TUTU, D. 1994. The rainbow people of God: South Africa's victory over apartheid. Ed. by J. Allen. London: Doubleday.

TUTU, D. 1998. The Truth and Reconciliation Commission (In Du Toit, C.W., ed. Confession and reconciliation. Pretoria: Unisa. p. 3-6.)

VILLA-VINCENCIO, C. 2000. Getting on with life: a move towards reconciliation. (In Villa-Vicencio, C. \& Verwoerd, W., eds. Looking back, reaching forward: reflections on the Truth and Reconciliation Commission of South Africa. Cape Town: CT Press. p. 199-209.)

VORSTER, J.M. 2004. Ethical perspectives on human rights. Potchefstroom: Potchefstroom Theological Publications.

VORSTER, J.M. 2007. Christian attitude in the South African liberal democracy. Potchefstroom: Potchefstroom Theological Publications.

WILSON, R. 2001. The politics of truth and reconciliation in South Africa: legitimising the post-apartheid state. Cambridge: CU Press.

\section{Key concepts:}

making Africa home

ministry of presence

ministry of reconciliation

resources for reconciliation

spirituality of reconciliation

\section{Kernbegrippe}

bediening van teenwoordigheid

bediening van versoening

gees van versoening

hulpbronne vir versoening

maak Afrika jou tuiste 
Taking responsibility for reconciliation: a Christian response to legacy ... 